\title{
Evolution of the Links between Research and Applications in Psychology across the United States and France: Illustrations and Consequences of an Endless Conflict
}

\author{
Marie Santiago-Delefosse ${ }^{1}$ \\ ${ }^{1}$ University of Lausanne, Department of Psychology, Switzerland \\ Correspondence: Marie Santiago-Delefosse, University of Lausanne, Geopolis, Psychology, 1015 Dorigny, \\ Lausanne, Switzerland. Tel: 41-692-3283. E-mail: marie.santiago@unil.ch
}

Received: February 13, 2015

Accepted: March 3, 2015

Online Published: May 29, 2015

doi:10.5539/ijps.v7n2p74

URL: http://dx.doi.org/10.5539/ijps.v7n2p74

\begin{abstract}
The author focuses on a historical analysis of the conflicting links between what is called "applications" or "practices" on the one hand and "theoretical research" or "experimental research" or "fundamental research" on the other, by following trends and cultures. Despite numerous declarations of intent advocating the need to link practices and theories, the fact remains that both types of psychology tend to move further and further away from this aim, since the birth of psychology. This growing gap questions the possibility of a total division between "applied psychology" and "fundamental psychology". First, the author discusses the complexity of the terms used by the different authors, such as "applied psychology", "practical psychology" and "concrete psychology", compared to other terms such as "academic", "experimental", "theoretical", "fundamental psychology", etc. These different names are considered as an indicator of the fluctuations in the relationship between applications and theories. Second, the author shows that the field categories in psychology were built upon different foundations in France and underlines the consequences of this process. This viewpoint will be illustrated by a French case: that of the creation and dissemination of a new psychological discipline at the end of the $80 \mathrm{~s}$. The interest of this example is that it shows the disparities between the academic theories and practical developments. In addition, it allows us to highlight its tension lines, with considerable consequences for students and practitioners. The discussion shows the need to implement a real space that enables the analysis of concrete practices by psychologists considered as producers of new knowledge, and in this way to make the construction of new psychology models possible.
\end{abstract}

Keywords: applied psychology, concrete psychology, academic psychology, experimental psychology, conflicting links

\section{Introduction}

This text (Note 1) focuses on a historical analysis of the conflictual links between what is called "applications" (Geissler, 1917) or "practices" (Munsterberg, 1917) on the one hand and "theoretical research" or "experimental research" (Danziger, 1985) on the other, following trends and cultures. Indeed, despite numerous declarations of intent advocating the need to link practices and theories, the fact remains that both types of psychology tend to move further and further away from this, since the birth of psychology (Driesch, 1925; Cartwright, 1978). This distancing will even question certain researchers, as we will see, on the need for a total division between applied psychology and fundamental psychology.

In this article, we start by presenting the complexity of the evolution of the terms "applied psychology" (Geissler, 1917), "practical psychology" (Munsterberg, 1915) and "concrete psychology" (Politzer, 1928) compared to "academic", "experimental", "theoretical", "fundamental psychology" (Boring, 1950). We follow the debates on the various names given to "applied psychology" in the United States from its beginning to the end of the 19th century. These semantic debates, far from being anecdotal, show the fluctuations in the relationships between applications and theories (Kanfer, 1990; Louw, 1993).

Second, we briefly show how the categories of the various psychology fields were built on different foundations in France and what the consequences were. We illustrate our viewpoint with a case: that of the creation and dissemination of a new psychology discipline in France at the end of the 80s. Health psychology as designed in 
the United States. The advantage of this case is that it shows the disparities between the academic theories and practical developments and helps to better highlight the tension lines (Santiago-Delefosse, 2012). This comparison also underlines the risks of taking these concepts from a given culture without being aware of its historical origins, or of the debates taking place within that culture (Bayer \& Shotter, 1998).

Lastly, we question the need for a real space to analyse concrete practices of psychologists as "knowledge producers". Based on our historical review, we argue that such analysis (both, academic and applied) would be the best way to contribute to build new models in psychology. This refers to the necessity to define theoretical models that are anchored within the field research, which could ideally become a "fundamental field psychology" (Munsterberg, 1915; Vygotsky, 1927, 1930; Shotter, 1980).

\section{Terminological Developments of "Applied" Psychology in the United States}

\subsection{Topicality}

Defining "applied psychology" remains difficult because the task requires us to acknowledge a wide variety of conceptualisations of psychology. In addition, as we shall see, the term does not carry quite the same connotations in France as it does in the English-speaking world.

In the briefest terms, we can speak of two major conceptions of applied psychology (Jahoda, 1990; Sanderlands, 1990; Semmer, 1993; Schönplug, 1993a, 1993b). One of these has its origins in academia and is based in experimental research. Within this conception, practitioners in the field are bound by the models which basic researchers produce. Advocates of experimental research and a majority of psychology professors, including applied psychology researchers, argue in favour of this perspective, based on the view that applied psychology is the application of academic theory to the public outside the laboratory. One advantage of this view is that it unifies psychology as both "science" and "profession" (Geissler, 1917; Goldstein, 1986).

The second major conception of the links between academic theory and its applications states that practices in the field are sources of new knowledge. In this view, practice produces "specific knowledge", which cannot be reduced to the application of theory (Von Mayrhauser, 1993; Hallinan, 1996). This conception has held currency in varying degrees since the beginnings of applied psychology: it first emerged in the United States during the 1920s, followed by variants in France, Switzerland and the Soviet Union during the 1930s and, more recently, has garnered increased interest since the 1980s (Dewey, 1917, 1985; Baldwin, 1897, 1930; Bülher, 1927; Driesch, 1925; Vygotsky, 1927; Mead, 1909, 1938; Stivers \& Wheelan, 1986). Applied psychology, in this view, represents a form of self contained research that is carried out in the course of practice, through practice and with a focus on practice. In this perspective, we speak less of "applied psychology" and more of "psychological practice".

The debate between these two conceptions has persisted, through various permutations, since the emergence of psychology in the 19th century and remains vigorous today. It is a debate between two epistemological approaches, two ways of conceiving practices and, indeed, two ways of understanding the links between theory and application. It involves, in fact, two visions of our profession, in which we are either "informed appliers" or "practicing investigators".

An analysis of the terminological developments of "applied psychology" in the American context provides an illustrative starting point from which to tackle the conceptual, methodological, social and institutional issues at stake.

\subsection{The 1920s: "Applied" Psychology or "Second Psychology"?}

Applied psychology has its origins in the Enlightenment debate that pitted clerical thinking against currents of philosophy that sought rational foundations for the human subject. Two major theories of the individual emerged from this debate: that of experimental, objectivist psychology and that of the social individual situated in cultural and political contexts. Debates between these conceptions continued through the 19th century and were further nuanced by the pragmatic and utilitarian thought, which sought to put an end to speculative conceptual arguments through a focus on "empirical facts". The encounter of these differing influences contributed to the creation of the first major experimental psychology laboratories and the emergence of applied psychology (Jahoda, 1990).

At the beginning of the 20th century, applied research focused on understanding human action and the impact of the human factor, as situated in complex contexts in which decision making, organisation, and production were seen as essential functions. 
In the first issue of Applied Psychology, Ludwig Reinhold Geissler (1917) (Note 2) stated that applied psychology corresponded to what was also known as "practical psychology", "psychotechnics" or "psychotechnology" and was opposed to "pure", "theoretical" or "general psychology" (or "academic/experimental psychology") as developed within the confines of university laboratories.

For Geissler, applied psychology was more akin to art than to science and was to focus on improving the human condition rather than becoming mired in intellectual discussion. Geissler's definition was closely in line with contemporary social demand for measuring instruments that could increase human productivity and efficiency (at work and school, for example). Importantly, this definition of applied psychology allowed its proponents to relegate potential analyses of practices and of the role of practitioner-researchers to the background, thus widening the gap between theory and practice to the detriment of any methodical examination of existing divergences.

Other authors during the same period proposed a different approach to "applied" psychology, however. Notable among them was Hugo Münsterberg (1863-1916), a former student of Wilhelm Wundt (Blumenthal, 1980, 1985), associate of William James (1890) and director of Harvard's psychology laboratory, who pioneered various branches of applied psychology in the United States (criminal, clinical, work and industrial psychology, among others).

Münsterberg $(1913,1915)$ formalised two necessary and inseparable currents: causal psychology (the psychology of mental states, using experimental methods) and teleological psychology (the psychology of the individual, using social science methods with a focus on meaning). It is the latter current that became known as "second psychology". In Münsterberg's view, this psychology was to concentrate on individuals as producers of meanings who project themselves into the future, viewing subjects within specific contexts and employing methods specifically suited to this type of study (Münsterberg, 1915; Chandler, 2002). Among those who followed this path and developed methods and studies closely linked with fieldwork were Jean Piaget in Geneva (Cahan, 1984), Heinz Werner in Hamburg (1940), Lev Vygotski in Moscow (1927; Wertsch, 1981), and Henri Wallon in Paris (1938).

\subsection{The 1930s, 40s and 50s: Economic Crisis and the Role of Philanthropic Foundations}

One of the effects of the economic crisis of the 1920s was an intensification of "utilitarian" and pragmatic pressures. Subsequently, three forms of psychology coexisted during the 1930s and 1940s.

1) University researchers developed academic (experimental) psychology, proclaiming it the sole representative of scientific psychological research.

2) Münsterberg's "second psychology" advocated the use of clinical and qualitative methods in the study of situated activity. It also held currency in universities (Moore, 1978; Geiger, 1986), but quickly entered into conflicts of interest with academic/experimental psychology (Freyd, 1927; Danziger, 1988).

3) The third form, “applied psychology”, which was closer to Geissler's pragmatism, quickly spread beyond academia, largely due to the support of private philanthropic foundations.

In the view of many philanthropic foundations, research in psychology was to be concerned exclusively with the practical problems of everyday life; it was to be oriented towards, in their definition, "useful" objectives. Philanthropic foundations supported work specifically dedicated to individuals' well-being (Note 3). They contributed to the financing of significant methodological innovations, as well as to the promotion of the psychological discipline among the general public, while at the same time increasing the social control function of applied research (Ross, 1991; Chandler, 2002). In the period following the Second World War, Münsterberg's "second psychology" was gradually supplanted by the discipline's experimental current. Subsequently, philanthropic foundations became major contributors in the financing of applied research in psychology and the social sciences (McKeachie \& Brim, 1984).

This was the context in which American universities first designed applied research curricula for practitioner-researchers in the late 1949s (Harvard University, 1947; Moore, 1978). The curricula of academic/experimental psychology cohabited with applied psychology, but defined it as applying the models and theories produced by the more "scientific" approach (Freyd, 1926) (Note 4). There thus emerged a "marriage of convenience" between academic applied psychology and academic experimental psychology, from which both perspectives drew benefits: the former was able to attract greater numbers of students, while the latter was better able to ensure financing for its laboratories. 
2.4 From the 1990s to the Present: An Ongoing Debate, a Thriving Semantic Field, a Turn towards "Practices" ("Applied Psychology", "Practical Psychology", "Investigative Practice", "Knowing of the third kind")

Debates on the definition of applied psychology and its object of study returned to the fore during the 1990s (Schönpflug, 1993a, 1993b), when proponents of three major perspectives vied for predominance.

1) Some advocated an "applied psychology" that was in line with academic/experimental psychology (Von Mayrhauser, 1993).

2) Others supported a relatively independent applied psychology that accorded place to the contributions of the academic/experimental viewpoint, in an approach similar to Münsterberg's second psychology (Cahan \& White, 1992).

3) Others yet backed an entirely independent applied psychology as an integral practice and research discipline unto itself (Louw, 1993).

Although relatively diverse as a group, proponents of entirely independent applied psychology generally argued for a "practical psychology", which draws on the contributions of psychological practices exercised in context. These authors argued that practices produce new knowledge through their effects in context and that analyses of practices produce new learning and new models (Semmer, 1993; Sugiman, 2006).

Certain authors argued also that the differentiation of "practice" and "theory" originated in the postulate that "theoreticians" and "experimentalists" could not claim to exercise any "practices" by which to characterise their work. In this view, therefore, theory (knowing "what") and practice (knowing "how") are inseparable (Stivers \& Wheelan, 1986; Sandelands, 1990). Thus, to place theory and practice in opposition was to avoid studying the links between them, neglecting the knowledge produced by their joint action (Shotter, 1980, 1993a, 1993b; Hill \& Morf, 2000). Danziger (1987, 1994), in particular, proposed a focus on "psychologists" "investigative practices", which he saw as the precise analysis of the work exercised by psychologists in the various contexts of their work. This analysis was to favour the development of theories connected to the reality of psychologists' work, as well as the comprehensive examination of their activity through dialogic interaction, integrating contingent social aspects (Note 5). Examining the joint action of theory and practice, in this view, would produce new psychological, a knowledge "knowing of the third kind" (Shotter, 1997).

Briefly speaking, therefore, in the past thirty years we have seen a gradual shift from a conception of practice as the reproduction of theory in non-experimental settings towards that of a critical questioning of the foundations of applied psychology. Increased interest in "investigative practices" and in the knowledge produced by the joint action of theory and practice in the course of psychologists" work signals a turn towards the analysis of practices and, indeed, towards a new conception of practices as integral sources of knowledge (Note 6).

\section{France: From "Applications of Psychology" to "Psychological Practices"; Different Debates in a Different Culture.}

\subsection{From the Late 19th Century to the 1920s: Experimental Psychology Laboratories Spur the Emergence of the "Applications" of Psychology}

The position of applied psychology in France has been conditioned by a distinct set of cultural and historical developments, producing specific categories and concepts. Notable among many other differences is that divisions within the discipline in France have not followed the American pattern of opposition between academic/experimental and applied psychology (Carroy, Ohayon, \& Plas, 2006).

In the late 19th and early 20th centuries, it was the directors of French experimental laboratories who provided support for applied psychology. In those early days, laboratory directors in France were often psychiatrists, working in hypnosis and influenced by work in biology, or philosophers specialising in the humanities and linguistics. Work in French experimental laboratories during the period produced applications in many domains, including :

1) Pathological psychology, including work on hysteria, hypnosis, etc. (Charcot, Ribot, Janet) (Bonduelle, Guelfand, \& Goetz, 1996; Ribot, 1900; Janet, 1889, 1929).

2) The social psychology of Tarde (1902) and Le Bon (1895).

3) The first psychometric tests, developed by Binet (1903) and Simon (1904).

4) Lahy's selection tests (Edouard Toulouse and Maurice Lahy founded a psychotechnics laboratory for the Paris transit authority in 1924) (Lahy, 1916; Toulouse, 1910). 
These developments were not, however, identified as "applied psychology". Indeed, the term was only rarely encountered during the period. They were rather seen as the "practical" extensions of the results of research in laboratories, most often categorised according to sub-discipline, such as general, clinical, social, counselling, school, or work psychology. In 1929, Pierre Janet (1859-1947), the research Chair in experimental and comparative psychology at Collège de France, noted that "psychology would be futile if it satisfied only the authors of philosophical systems, without any value to the public, to the merchant, for example, who may say: I would like for this to help me make money" (Carroy, Ohayon, \& Plas, 2006, p. 185).

\subsection{Between Two Wars: A Broad Expansion of Applications Driven by Laboratories and their Directors}

In the inter-war period, pressing social needs contributed to an increase in the demand for psychological applications in the domains of work, professional assessment and counselling, among others. In the field of psychopathology, psychiatrists advocating for a pathological psychology (whether biological or social) began to promulgate their ideas through journal publications, driving forward the idea of an independent "new, practical, essentially clinical psychology" (eg. L'Evolution Psychiatrique, first published in 1925).

Many directors of experimental/academic psychology laboratories reacted to these developments by insisting on the social and political dimensions of the increased social demand for applications (Henri Wallon, 1879-1962, Laboratoire de psychobiologie de l'enfant EPHE-Wallon, 1938). Henri Piéron, founder of the Institut de Psychologie and director of the experimental psychology laboratory at the Sorbonne, succeeded in making the counseling psychology curriculum the first branch of applied psychology to achieve the status of a recognised university degree programme, in 1938 (Piéron, 1949). It is interesting to note that Piéron's conception of the links between theories produced by laboratory research and their applications in the field was at once thoroughly positivist and profoundly engagé politically. Piéron wanted psychology to help secure the individual's place in rational social organisation, to rectify class privileges in favour of those less capable, since the community loses out on the benefit of high skills when these are ignored because they belong to classes that are effectively sacrificed (Piéron, 1949).

Throughout the development of the "science" of psychology, until the 1960s, much research and laboratory work was devoted to developing applications designed to aid the emancipation of the working classes. This work, however, was not identified as applied psychology, but as the direct application of laboratory work. It was only in 1959 that a Revue de Psychologie Appliquée first appeared, published by a private research centre involved in the production of psychometric tests.

During the 1930s, the field's greatest concern were abuses of psychology outside of the laboratory, given the increased numbers of untrained individuals attracted by the social demand described above. This period also saw the first extensive critiques of psychology, which, originating in philosophy, questioned the discipline's conceptual and methodological approaches.

In 1928, in his Critique des Fondements de la Psychologie, Georges Politzer opposed idealised and abstract approaches to psychology, in opposition to which he proposed a "concrete psychology" focused specifically on the individual and the individual's lived experience as a synthesis of individuals' behaviours and the meaning they accorded to their actions. This "concrete psychology" was to be both a research method and a practice based in the "fieldwork" of everyday life. Politzer's definitions have much in common with Münsterberg's "second psychology", whose conception of a psychology anchored in specific practices later influenced not only the founders of the new psychology of the 1950s (Lagache, 1949; Merleau-Ponty, 1945), but philosophers (Foucault, 1954; Canguilhem, 1958) as well. Following the temporary discontinuation of these debates during the Second World War, Daniel Lagache established France's first Bachelor's degree in psychology in 1947.

\subsection{The 1950s: Academic Experimental Psychology and Academic Clinical Psychology in Opposition; Method and Practice as Generators of New Knowledge}

From the beginning of the 1950s, the combined influence of two opposing camps resulted in the separation of university psychology programmes from philosophy: experimental psychology researchers, who strove for recognition as "scientists", and clinical/pathological psychology researchers, who sought to establish a distinct profession.

It was during this decade that Daniel Lagache (1903-1972), psychiatrist, philosopher and psychoanalyst, played a major role in firmly establishing psychology as a research discipline in French universities and as a new profession. Lagache believed that psychology was fundamentally unified, despite the existence of the two major contrasting methodologies of the discipline's experimental and clinical branches; Lagache identified the psychoanalytical method as belonging to the clinical branch (1949). 
Consequently, for Lagache, psychological applications and, in particular, clinical psychology could not be reduced to an applied psychology. It was both a research method and a fertile professional practice that together generated new, distinct and specific knowledge.

\subsection{The Emergence of Clinical Psychology in Health Settings: A New Field of Professional Practice}

Among Lagache's numerous contributions to the field during the 1950s was his elaboration of a new sub-discipline of clinical psychology, closely linked with "medical psychology". Remarkably, the objectives which Lagache elaborated for clinical psychology in 1955 remained relevant in 1980, when the APA published its definition of health psychology (Lagache, 1955). According to Lagache, clinical psychology in health settings was to:

- extend psychological care to patients suffering from somatic illnesses;

- understand the effects and consequences of the physician-patient-family relationship;

- describe psychological traits comparatively to type and form of illness;

- and identify the impact of group values and beliefs, including their influence on such aspects as adherence to prescriptions and preventive recommendations.

Specific to Lagache's vision was that this approach to psychology in health settings was to be an integral part of clinical psychology, in the full acknowledgment of clinical methods and the contributions of psychoanalysis (Santiago-Delefosse, 2000, 2002). By the late 1950s, general hospitals (somatic health) were hiring clinical psychologists, whose education was primarily focused on clinical methods and psychoanalytic theory.

At this time, practising psychologists in health settings in France did not consider themselves to be practising "applied psychology" (Note 7). Nevertheless, questions on the social uses of psychology were being hotly debated in the pages of specialised journals and among the ranks of psychological associations.

3.5 The 1960s and 1970s: A Critique of the Role and Function of Psychologists as Researchers and Practitioners

Beginning in the 1960s, sustained critiques by philosophers (Foucault, 1954; Canguilhem, 1958), psychoanalysts (Roudinesco, 1982) and psychiatrists (Evolution Psychiatrique group) (Note 8), argued that the new generation of psychologists were neither philosophers, nor psychoanalysts, nor physicians. It was the philosopher and physician Georges Canguilhem (1904-1995) who formulated the most enduring of these critiques when he questioned the discipline's status and foundations, as well as its function as an instrument of social control. For Canguilhem, "Psychology is a discipline whose status remains unfixed and which lacks foundations. It draws in unequal and uncontrolled measure on philosophy, on psychiatry, and on received ideologies about social roles and positions... A great deal of researches in psychology mix: a philosophy without rigour, ethics without exigency, and medicine without control" (Canguilhem, 1958). Canguilhem warned, moreover, against the social use of insufficiently controlled social practices in the service of power. Not without of a sense of humour, he recalled that when one "exits the Sorbonne onto the rue Saint-Jacques, one can walk either uphill or downhill; if you turn uphill, you get closer to the Panthéon, where several great men are preserved, but if you go downhill, you most assuredly wind up at the Police Prefecture" (1958).

\subsection{From 1985 to the Present: The Institutionalisation of Psychology Intensifies, "Health Psychology" Emerges}

In 1985, France adopted legislation regulating the exercise of the psychological profession. In defining the parameters of practitioners' activity, the new law contributed to the institutionalisation of psychology. The legislation reserved the title of psychologist to individuals having completed a minimum of 5 years of higher education in the discipline (equivalent to the combined duration of Bachelor's and Master's degrees) and having obtained a high-level diploma, signifying adequate training in research and practices. In doing so, the law responded to the concerns of professional associations at a time of accelerated influx of new students into psychology programmes in French universities. In fact, the numbers of French students enrolling in psychology programmes had been on the rise since 1980. For the most part, these new entrants opted for curricula leading to career paths in children's education and health settings, rather than extended academic careers. The most employable degrees in psychology at the time were those in work psychology, childhood psychology and clinical psychology. These were, consequently, the options taken by most students. In response to this trend, some researchers working in laboratory and basic research sought to link their work more closely with applications so as to attract students to their research areas; avec ces changements, peut-être que la phrase précédente devient moins nécessaire? (For the most part, these new entrants opted for curricula leading to career paths in children's education and health settings, rather than extended academic careers). 
This was the context into which health psychology arrived from the United States at the beginning of the 1990s. The French researchers who subsequently contributed to the field had closer ties with experimental laboratories and psychobiology than with clinical psychology (Note 9); they were even less closely tied with clinical psychology in health settings, which had already developed a strong background in practices since the 1960s. They thus carried over with them curricula and research directions marked by the assumptions of applied psychology, as developed by Geissler and experimental researchers in the United States during the 1960s.

\subsection{American Mainstream Health Psychology: A Rejection of Active Practice}

Seen by many as a transplantation of ideas from experimental psychology, the new stream of health psychology did not enjoy a warm reception in France (Giami, 1997). Researchers in clinical psychoanalytic psychology, in particular, were wary of what they perceived as a challenge to clinical methods and psychoanalytic theory.

The most extensive critiques, however, came from professional associations and practitioners, who based their arguments on their practices. Importantly, they objected to being reduced to the role of "appliers" of methods and questionnaires developed in laboratory research; they objected also to the imposition of socio-cognitive and behavioural theories akin to bio-medical thought. And, in addition, they questioned the ethics of practices that paid scant attention to individuality and distinct life experiences (Sidot, 1997).

Thus the encounter of health psychology and the long French tradition of clinical psychology in health settings may best be described as a head-on collision. Since most French practitioners formulating these critiques were likely unfamiliar with the discipline's debates in the English-speaking world, most also likely did not know how closely their ideas aligned with English-language discussions on critical psychology. In addition, French practitioners' thinking on these issues also paralleled the "turn towards practices", which emerged from reflections on the links between theory and practice. Their critiques, operating on the conceptual, methodological, professional and ethical levels, argued that health psychology was characterised by:

- an individualistic, reductive conception of linear causality;

- a lack of reference to subjectivity and subconscious mechanisms;

- an absence of a psychological theory of the human individual;

- the application of socio-cognitive experimental research theory without reference to fieldwork knowledge;

- a widening of the gap between theory and practice;

- the paramedicalisation of the profession as an adjunct of medical practice, employed only to aid its efficiency and comfort;

- a reduction of psychologists to the role of "appliers" of theory within bio-medical models;

- and a failure to reflect on psychological ethics.

The arrival of health psychology in France resulted in a clash of cultures. In 1997, the president of the European Society of Health Psychology, reflected on the discipline's reception in France: "With our first conference in France, we are making another significant step towards becoming a Society that truly represents all health psychologists in Europe ... Since France has been under-represented in our Society so far, I am curious about the long-term effects of the meeting in Bordeaux." (Schwarzer, President, EHPS Newsletter, 1997).

\subsection{Practicing Psychologists: Recognising the Role and Importance of Practices as Contributions to the} Production of Knowledge

Clinical psychology in health settings remains a dominant force in psychological practice. Over time, health psychology curricula have become increasingly diversified under the influence of individual researchers and university programmes. Some, though not many, continue to teach mainstream health psychology on its own. Most, however, have integrated its contributions into the wider scope of psycho-social and clinical knowledge (Note 10).

In France, the discipline's conceptual and methodological rivalries have not been put to rest and practitioners continue to vociferously argue that professional practices are generators of knowledge, rather than simply applications. In 2006, a public petition signed by French practicing psychologists, which even garnered media attention, asserted their conception of psychological practices and their rejection of the profession's medicalisation by insisting that:

- Psychology, which has its origins in philosophy, belongs to the social sciences and evolves through practices based in dialogue and exchange. 
- Psychologists working in the health field seek to re-establish the patient's connection between the somatic and the psychic, with regard to each individual's history.

- Medicine and psychology are two fundamentally distinct disciplines, which are sometimes complementary, but in no circumstance is it possible to substitute one for the other or to subordinate one to the other.

The two currents of health psychology operating in France propose radically different conceptions of "applications". Adherents of mainstream health psychology continue to advocate the application of theories originating in academic knowledge and research laboratories. Adherents of clinical psychology in health settings, on the other hand, argue that intervention and research practices must be designed so as to allow for the generation of new knowledge, placing particular emphasis on psychologists' research, everyday practice and ethics.

\section{Discussion: Theorising Practice, towards a Basic Fieldwork Research?}

As we have seen, discussions in the United States and in France-although originating from different premises and operating in unconnected categories - have nevertheless arrived at similar positions and produced comparable results. If the existing oppositions are to be transcended, however, current positions in social science research must change, as must also, by consequence, the methods of acquiring knowledge. Such transformation requires basic research in the field to focus on the concepts that construct facts, on the realities that underpin them, and on the tools used to establish models and interpret theories.

Ultimately, it is practice - whether in psychopathology, psychopedagogy, criminal psychology, work psychology or organisational psychology - that allows us to contrast conceptually idealistic positions with the effects of fieldwork. Practice, therefore, cannot be considered as merely a platform for the application of theory or as the end result of theory. On the contrary, in fact, practice is the anchor and the compass of theory in the advancement of social science (Argyris \& Schon, 1976; Barlow, Hayes, \& Nelson, 1984; Kanfer, 1990; Hill \& Morf, 2000). Writing in 1927, Vygotsky expressed a similar view when he stated that the way out of the crisis between causal and teleological psychology required the analysis of practices, indeed, practice insinuates itself into the deepest foundations of the research process and transforms it, from beginning to end Vygotski (1927/1999): "The most complicated problems of psychological methodology are transplanted into the field of practice and it is only there that solutions to them may be found. There, discussion ceases to be sterile, it is over. "Method" means "way"; we think of it as a means of gaining knowledge, but the way is determined in all respects by the end to which it leads. That is why practice restructures all methodology in science". (Vygotsky, 1927, p. 236)

Danziger's work on investigative practices and the analysis of methodologies, which allows us to understand what it is we do and to theorise the psychologist's activity, takes a similar direction. We must however remain careful not to confound "theorising" with "rationalising", in particular when investigating practices.

"Rationalisation" is the purview of intellectualisation mechanisms that ignore field-based knowledge, resulting in theories viewed as indisputably applicable in the field. This is entirely different from the tension at play between theory and practice, when practice is both the starting point and the culmination of the process. Analyses of this tension must define the constituent parts of practice and the causes and means of its operation, as well as question its contradictions and limits, seeking to account comprehensively for its development, character and meaning. The analysis of the researcher's activity is part of the methodology, as is the historical analysis of the methodological apparatus, including its assumptions, ideological and epistemological foundations, and its dynamic. The intersection of Danziger's work on investigative practices and Vigotsky's methodology for "analyses of the traces of activity" reveals the importance of practices which are decidedly not mere "applications". In fact, practices structure interventions, methodologies and theories to such a degree that their analysis could provide the anchor and the compass of future directions in research for various disciplines.

Such a methodological utopia, however, necessitates two components: first, laboratory research must focus on its own practices, methods and potential conceptualisations in order to understand how and why it establishes specific practices of inquiry; second, fieldwork analyses must avoid overly concentrating on the "subject's truths" and extend their scope to include methods of intervention, as well as the underlying frameworks and the types of knowledge they generate. This joint methodological outlook remains to be constructed (Santiago-Delefosse, 2012).

\section{Conclusion}

This brief historical overview of the conceptual developments of "field", "applied", "second" (Cahan \& White, 1992), "concrete" (Politzer, 1928), "practical” (Sanderlands, 1990; Craig, 1996), "investigative” (Danziger, 
1987), and "third kind" (Shotter, 1993) psychology has highlighted the key challenges of the attempts to define applied psychology.

The comparison between the United States and France shows the risks underlying the act of taking certain concepts from one culture and to transfer them to another one, without any awareness of internal debates or origins of the borrowed concepts. By following this approach, there is the risk of stressing the misunderstandings and oppositions towards a given theoretical perspective because of a badly known terminology. Be that as it may, both in the United States and in France, the debate to acknowledge the theoretical contributions from field practices remain open. No matter the eventual outcome of these debates, whether they lead to the discipline's independence or not, it is clear that since the 1970s increasing numbers of researchers have refused to view the psychology of practitioners as no more than a platform for the application of academic theory (Danziger, 1987, 1990; Schotter, 1993b).

Inquiries have shifted towards the search for a deeper understanding of practices and their effects, that is, towards analyses of the exercise of practices (both in the field and the laboratory). This "practical and concrete psychology" (Politzer, 1928) has the benefit of focusing on the analysis of real psychological practices as generators of psychological knowledge (Vygotsky, 1927; Kozulin, 1990). The approach helps to tie together practice and theory, thereby acknowledging the creative role of practitioners in the field, opening onto a psychology that is not averse to practices and a reflexivity on those practices (Meyerson, 1947; Argyris \& Schon, 1976). The tying together of practices and conceptual models implies that without conceptual reflexivity there can be no transferable practices to contribute to the development of knowledge; by the same token, without practices there can be no theory, only intellectualisations that idealise the possible applications of theory. As our brief historical review shows, this, indeed, is the fundamental difference between an applied psychology in the service of utilitarian pragmatism and a practical psychology that allows for basic research in the field (Sugiman, 2006; Santiago-Delefosse, 2012).

The integration of "first" and "second" psychology sought by Münsterberg (Münsterberg, 1915) has not yet become reality and neither has Danziger's (Danziger, 1987) wish for the primacy of investigative practice. A developmental psychology focused on the analysis of traces of activity, as envisioned by Vygotsky (Vygotsky, 1927; Del Rio Carral \& Santiago-Delefosse, 2015), remains to be developed at the level of practices and methodological tools. Linking laboratory inquiry with inquiry in the field through the medium of analyses of psychologists' activity offer an avenue: not of reconciliation and, even less so, of unification among the branches of psychology, but one serving to set them in mutual tension. Such tension would provide an additional level of opportunity for the production of knowledge in the links between practice and theory.

Failing such a setting in tension, we will continue to have theory that is inconsistent with work in the field and practices without underpinnings, increasingly tied to illusory facts of lived experience, making impossible any effective modelling of their activity and modes of action. For now, the research practices [methods?] of "basic grounded psychology" remain to be developed, as do the models that will allow for its formalization (Note 11).

\section{References}

Abelhauser, A., Doucet, C., \& Gaspard, J. L. (2011). Pratiques et usages du corps dans notre modernité. Paris: Eres.

Allport, F. H. (1924). Social psychology. Boston: Houghton Mifflin.

Argyris, C., \& Schon, D. A. (1976). Theory in practice: Increasing professional effectiveness. San Francisco: Jossey Bass.

Baldwin, J. M. (1897). Social and ethical interpretations in mental development: A study in social psychology. New York: Macmillan. http://dx.doi.org/10.1037/12907-000

Baldwin, J. M. (1930). James Mark Baldwin. In C. Murchison (Ed.), A history of psychology in autobiography (Vol. 1, pp. 1-30). Worcester: Clark University Press. http://dx.doi.org/10.1037/11401-001

Barlow, D. H., Hayes, S. C., \& Nelson, R. O. (1984). The scientist practitioner: Research and accountability in clinical and educational settings. New York: Pergamon Press.

Bayer, B., \& Shotter, J. (1998). Reconstructing the psychological subject: Bodies, practices, and technologies. Thousand Oaks: Sage. http://dx.doi.org/10.4135/9780857026019

Binet, A. (1903). L'Etude expérimentale de l'Intelligence. Paris: Schleicher Frères Editeurs. 
Blumenthal, A. L. (1980). Wilhelm Wundt and early American psychology: A clash of cultures. In R. Rieber (Ed.), Wilhelm Wundt and the making of a scientific psychology. New York: Plenum Press. http://dx.doi.org/10.1007/978-1-4684-8340-6_4

Blumenthal, A. L. (1985). Wilhelm Wundt: Psychology as the propaedeutic science. In C. E. Buxton (Ed.), Points of view in the modern history of psychology. San Diego: Academic Press.

Bonduelle, M., Gelfand, T., \& Goetz, C. G. (1996). Charcot, un grand médecin dans son siècle. Paris: Éditions Michalon.

Boring, E. G. (1950). A history of experimental psychology. New York: Prentice-Hall.

Bruchon-Schweitzer, M. (2002). Psychologie de la santé: Modèles, concepts et méthodes. Paris : Dunod.

Bruchon-Schweitzer, M., \& Dantzer, R. (1994). Introduction à la psychologie de la santé. Paris : Puf.

Bühler, K. (1927). Die Krise der Psychologie. Iéna: Verlag Gustav Fischer.

Cahan, E. D. (1984). The genetic psychologies of James Mark Baldwin and Jean Piaget. Developmental Psychology, 20, 128-135. http://dx.doi.org/10.1037/0012-1649.20.1.128

Cahan, E. D. (1992). John Dewey and human development. Developmental psychology. http://dx.doi.org/ 10.1037/0012-1649.28.2.205

Cahan, E. D., \& White, S. H. (1992). Proposals for a second psychology. American Psychologist, 47(2), 224-235. http://dx.doi.org/10.1037/0003-066X.47.2.224

Canguilhem, G. (1958). Qu'est-ce que la psychologie? Revue de métaphysique et de morale, 63(1), 12-25.

Carroy, J., Ohayon, A., \& Plas, R. (2006). Histoire de la psychologie en France. Paris: La Découverte.

Cartwright, D. (1978). Theory and practice. Journal of Social Issues, 34, 168-180. http://dx.doi.org/10.1111/ j.1540-4560.1978.tb00782.x

Chandler, A. D. (2002). The visible hand: The managerial revolution in American business. Cambridge: Belknap.

Craig, R. T. (1996). Practical theory: A reply to Sandelands. Journal for the Theory of Social Behavior, 26, 65-79. http://dx.doi.org/10.1111/j.1468-5914.1996.tb00286.x

Danziger, K. (1980). Wundt's psychological experiment in the light of his philosophy of science. Psychological Research, 42, 109-122. http://dx.doi.org/10.1007/BF00308696

Danziger, K. (1985). The origins of the psychological experiment as a social institution. American Psychologist, 40, 133-140. http://dx.doi.org/10.1037/0003-066X.40.2.133

Danziger, K. (1987). Social context and investigative practice in early twentieth-century psychology. In M. G. Ash, \& W. R. Woodward (Eds.), Psychology in twentieth-century thought and society. New York: Cambridge University Press.

Danziger, K. (1988). A question of identity: Who participated in psychological experiments? In J. G. Morawski (Ed.), The rise of experimentation in American psychology. New Haven: Yale University Press.

Danziger, K. (1994). Constructing the subject: Historical origins of psychological research. Cambridge: Cambridge University Press.

Del Rio Carral, M., \& Santiago-Delefosse, M. (in press). Interpretation of Data in Psychology: A false problem, a True Issue. In Philosophy Study.

Dewey, J. (1917). The need for social psychology. Psychological Review, 24, 266-277. http://dx.doi.org/10.1037 $/ \mathrm{h} 0071213$

Dewey, J. (1985). Social science and social control. In J. A. Boydston (Ed.), John Dewey: The later works. (Original work published 1931). Carbondale: Southern Illinois University Press.

Doucet, C. (2007). Le Psychologue en service de médecine: Les mots du corps. Paris : Masson.

Driesch, H. (1925). The crisis in psychology. Princeton, NJ: Princeton University Press.

Fischer, G. N. (2002). Traité de psychologie de la santé. Paris : Dunod.

Fischer, G. N. (1998). La psychologie de la santé, champ théorique et intervention. Psychologues et psychologies, $141,40-41$. 
Fisher, R. J. (1982). The professional practice of applied social psychology: Identity, training, and certification. In L. Bickman (Ed.), Applied Social Psychology Annual. Beverly Hills: Sage.

Foucault, M. (1954). Maladie mentale et personnalité. Paris: PUF.

Freyd, M. (1926). What is applied psychology? Psychological Review, 33(4), 308-314. http://dx.doi.org/10.1037/ h0073383

Geiger, R. L. (1986). To advance knowledge: The growth of american research universities, 1900-1940. New York: Oxford University Press.

Geissler, L. R. (1917). What is applied psychology? Journal of Applied Psychology, 1(1), 46-60. http://dx.doi.org/10.1037/h0071582

Giami, A. (1997). La compliance des patients en question. Psychologues et psychologies, 139, 17-19.

Goldstein, H. (1986). Toward the integration of theory and practice: A humanistic approach. Social Work, 31, 352-357.

Gori, R., \& Del Volgo, M. J. (2005). La Santé totalitaire: Essai sur la médicalisation de l'existence. Paris: Denoël.

Hall, G. S. (1923). Life and confessions of a psychologist. New York: Appleton.

Hallinan, M. T. (1996). Bridging the gap between research and practice. Sociology of Education, 69, 131-134. http://dx.doi.org/10.2307/3108460

Harvard University. (1947). Committee to Advise on the Future of Psychology at Harvard: The place of psychology in an ideal university. Cambridge: Harvard University Press.

Hill, D. B., \& Morf, M. E. (2000). Undoing theory/practice dualism: Joint action and knowing from within. Journal of Theoretical and Philosophical Psychology, 20(2), 208-224. http://dx.doi.org/10.1037/h0091210

Jahoda, G. (1990). Our forgotten ancestors. In J. J. Berman (Ed.), Nebraska symposium on motivation, 1989: Cross-cultural perspectives. Lincoln: University of Nebraska Press.

James, W. (1890). The principles of psychology. New York: Holt. http://dx.doi.org/10.1037/11059-000

Janet, P. (1889). L'Automatisme psychologique. Paris: Masson.

Janet, P. (1929). L'Evolution psychologique de la personnalité. Paris: Masson.

Kanfer, F. H. (1990). The scientist-practitioner connection: A bridge in need of constant attention. Professional Psychology Research and Practice, 21, 264-270. http://dx.doi.org/10.1037/0735-7028.21.4.264

Keller, P. H. (2006). Le Dialogue corps-esprit. Paris: Odile Jacob.

Kozulin, A. (1990). Vygotsky's psychology: A biography of ideas. Cambridge: Harvard University Press.

Lagache, D. (1949). L'Unité de la psychologie. Paris: PUF

Lagache, D. (1955). Éléments de psychologie médicale. Euvres III. Paris: PUF.

Lahy, J. M. (1916). Le Système Taylor, et la physiologie de travail. Paris: Masson \& Cie.

Le Bon, G. (1895). Psychologie des Foules. Paris: PUF.

Louw, J. (1993). The history of psychology, applied psychology, and professionalisation. Applied Psychology, 42(1), 54-57. http://dx.doi.org/10.1111/j.1464-0597.1993.tb00722.x

McKeachie, W. J., \& Brim, O. G. (1984). Lessons to be learned from large behavioral research organizations. American Psychologist, 39(11), 1254-1255. http://dx.doi.org/10.1037/0003-066X.39.11.1254

Mead, G. H. (1909). Social psychology as counterpart of physiological psychology. Psychological Bulletin, 6 , 401-408. http://dx.doi.org/10.1037/h0072858

Mead, G. H. (1938). The philosophy of the act. Chicago: The University of Chicago Press.

Merleau-Ponty, M. (1945). La Phénoménologie de la perception. Paris: Gallimard.

Meyerson, I. (1947). Les Fonctions psychologiques et les œuvres. Paris: Albin Michel.

Mill, J. S. (1969). Auguste Comte and positivism. In J. Robson (Ed.), The collected works of John Stuart Mill: Essays on ethics, religion, and society. Toronto, Ontario, Canada: University of Toronto Press. 
Moore, J. (1978). The social science rebel at Harvard: An oral history of the Department of Social Relations. (Unpublished honors thesis). Radcliffe College. Cambridge : Harvard University.

Morin, M. (2004). Parcours de santé. Paris: Armand Colin.

Münsterberg, H. (1915). Psychology: General and applied. New York: D Appleton \& Company. http://dx.doi.org/10.1037/11627-000

Münsterberg, H. (2005). Psychology and Industrial Efficiency. Adamant: Media Corporation.

Peterson, D. R. (1991). Connection and disconnection of research and practice in the education of professional psychologists. American Psychologist, 46, 422-429. http://dx.doi.org/10.1037/0003-066X.46.4.422

Piéron, H. (1949). Psychologie différentielle. Livre premier du Traité de Psychologie appliquée. Paris : PUF.

Politzer, G. (1928). Critique des fondements de la psychologie. Paris : PUF.

Ribot, T. (1900). Essai sur l'imagination créatrice. Paris: Felix Alcan.

Ross, D. (1991). The origins of American social science. New York: Cambridge University Press.

Roudinesco, E. (1982). Histoire de la psychanalyse en France. Tome 1. Paris: Le Seuil.

Sandelands, L. E. (1990). What is so practical about theory? Lewin revisited. Journal for the Theory of Social Behaviour, 20(3), 235-262. http://dx.doi.org/10.1111/j.1468-5914.1990.tb00185.x

Santiago-Delefosse, M. (2002). Psychologie de la santé. Perspectives qualitative et clinique. Liège: Mardaga.

Santiago-Delefosse, M. (2000). Vers une psychologie clinique de la santé? Bulletin de Psychologie, 53(3), 333-341.

Santiago-Delefosse, M. (2012). The relevance of L. S. Vygotsky's developmental perspective to the debate on methodology in psychological science. Philosophy Study, 2(8), 515-526.

Schönpflug, W. (1993a). Applied psychology: Newcomer with a long tradition. Applied Psychology, 42(1), 5-30. http://dx.doi.org/10.1111/j.1464-0597.1993.tb00715.x

Schönpflug, W. (1993b). Practical and theoretical psychology: Singles with wedding rings? Applied Psychology, 42(1), 58-66. http://dx.doi.org/10.1111/j.1464-0597.1993.tb00723.x

Schwarzer, R. (1997). Message of the president. European Health Psychology Society Newsletter, 14, 1-2.

Semmer, N. (1993). Differentiation between social groups: The case of basic and applied psychology. Applied Psychology, 42(1), 40-46. http://dx.doi.org/10.1111/j.1464-0597.1993.tb00718.x

Shotter, J. (1980). Action, joint action and intentionality. In M. Brenner (Ed.), The Structure of Action. New York: St. Martin's Press.

Shotter, J. (1993a). Conversational realities: Constructing life through language. Thousand Oaks: Sage.

Shotter, J. (1993b). Cultural politics of everyday life: Social constructionism, rhetoric, and knowing of the third kind. Toronto: University of Toronto Press.

Shotter, J. (1997). Dialogical realities: The ordinary, the everyday, and other strange new worlds. Journal for the Theory of Social Behavior, 27, 345-357. http://dx.doi.org/10.1111/1468-5914.00042

Sidot, S. (1997). Task force: On health psychology. Médianop, 10, 3-4.

Simon, T. (1904). Méthodes nouvelles pour le diagnostic du niveau intellectuel des anormaux. L'Année psychologique, 11, 191-244. http://dx.doi.org/10.3406/psy.1904.3675

Stivers, E., \& Wheelan, S. (Eds.). (1986). The Lewin legacy: Field theory and current practice. New York: Springer-Verlag. http://dx.doi.org/10.1007/978-1-4615-8030-0

Sugiman, T. (2006). Theory in the context of collaborative inquiry. Theory \& Psychology, 16(3), 311-325. http://dx.doi.org/10.1177/0959354306064279

Tarde, G. (1902). Psychologie économique. Paris : Félix Alcan.

Toulouse, E. (1910). Enquête médico-psychologique sur la supériorité intellectuelle. Paris: Flammarion.

Von Mayrhauser, R. T. (1993). Applied dualism: An old deception in new employment. Applied Psychology, 42(1), 30-37. http://dx.doi.org/10.1111/j.1464-0597.1993.tb00716.x

Vygotsky, L. (1927). The historical meaning of the crisis in psychology: A methodological investigation (R. Van Der Veer, Trans.). The collected works of Vygotsky. New York: Plenum Press. 
Vygotsky, L. (1930). Mind in society: The development of higher psychological processes. Cambridge: Harvard University Press.

Wallon, H. (1938). Principes de psychologie appliquée. Paris : Armand Colin.

Werner, H. (1940). Comparative psychology of mental development. New York: International Universities Press, Inc.

Wertsch, J. (1981). The Concept of Activity in Soviet Psychology. New York: M.E. Sharpe Inc.

\section{Notes}

Note 1. Part of this research was the subject of a conference at the 28th International Congress of Applied Psychology.

Note 2. A native of Germany, Ludwig Reinhold Geissler held the position of Associate Professor of Psychology and Education at the University of Georgia from 1912 through 1916. Prior to his time at UGA, Geissler studied and taught under Professor E. B. Titchener at Cornell. In 1916, while at the University of Georgia, Geissler became the principal founder of The Journal of Applied Psychology with the aid of G. Stanley Hall and John Wallace Baird of Clark University in Worcester, Massachusetts. For Geissler, what is applied psychology depends (a) upon the meaning of the word "psychology", and (b) upon an understanding of the differences between "applied" or its synonyms and "pure" or its synonyms: "By 'applied psychology' we mean what is sometimes called practical psychology or psychotechnics or psychotechnology as opposed to "pure" or "theoretical" or "general" psychology. The aim of the applied sciences, on the other hand, is more prosaic, for they strive to enrich and improve the conditions and phases of human life and conduct, that is, they try to help us master or control difficult situations or meet them with more successful responses" (1917).

Note 3. In the period 1922-1929, the Laura Spelman Rockefeller Memorial Fund awarded 41 million dollars to interdisciplinary research on work and the social sciences.

Note 4. General and applied psychology are apparently not to be distinguished in regard to method. Although psychology cannot be applied, it can and should be made a broader and more practical science by enlarging its scope and making its experiments where people work and play as well as in the laboratory. The psychologist should be thought of as one who studies human behavior under all conditions without exception.

Note 5. It is neither purely conceptual knowledge, nor is it knowledge on the use of theories and methods; it is rather a "knowing of the third kind", which is co-constructed in and by action.

Note 6. Rather than as "reproducers" of existing models and theories.

Note 7. Near the end of my studies, in the late 1980s, I had been utterly stunned when the editor of a basic psychology journal informed me that a text I had submitted dealt with "applied psychology", when I had written on theoretical psychology and attendant methodological and clinical issues. The identity of clinical psychologists was based on Lagache's assumptions, in which the analysis of practices linked with the method of inquiry was to produce new basic knowledge.

Note 8. Such attacks point also to disputes and rivalries among researchers.

Note 9. Coming from a background in differential and social cognitive psychology, Bruchon-Schweitzer (1994, 2002) worked on the development and recognition of the mainstream health psychology. During the same period, Fischer $(1998,2002)$, with a background in social and community psychology, proposed a somewhat different definition. According to him, health psychology is "an approach that brings together various contributions from psychology, especially those of social psychology and of clinical psychology, and it takes into account the context of the illness and the social environment". Fischersdefinition should have been less liable to offend established "psychologists in health settings", because it is quite close to the one proposed by Lagache and leaves room for psychodynamic approaches.

Note 10. Bordeaux and Toulouse: Health Psychology mainstream (Bruchon Schweizer, 2002; differential psychology) - Aix-en-Provence: Social and health psychology (Morin, 2004) and Psychopathology (Gori \& Del Volgo, 2005)-Metz: Clinical and health psychology (Fischer, 1998; social clinical psychology)-Amiens: Clinical and Health Psychology (Santiago-Delefosse, 2002)-Poitiers: Psychoanalysis and psychosomatics (Keller, 2006) - Rennes: Psychoanalysis and medicine (A. Abelhauser, Doucet, \& Gaspard, 2011).

Note 11. These debates also touch on questions of researchers' training and their familiarity, or lack thereof, with practices in the field. Many researchers who teach either the one or the other branch of applied psychology hold, 
for the most part, an idealised vision of the field of application and its complexity. This in turn helps to explain their adherence to a vision of practice as a platform for the application of academic theories (whether applied or basic). The gap between such academic teaching and practitioners in the field keeps growing due to the lack of a thorough consideration of the knowledge and learning that practices produce in action.

\section{Copyrights}

Copyright for this article is retained by the author(s), with first publication rights granted to the journal.

This is an open-access article distributed under the terms and conditions of the Creative Commons Attribution license (http://creativecommons.org/licenses/by/3.0/). 